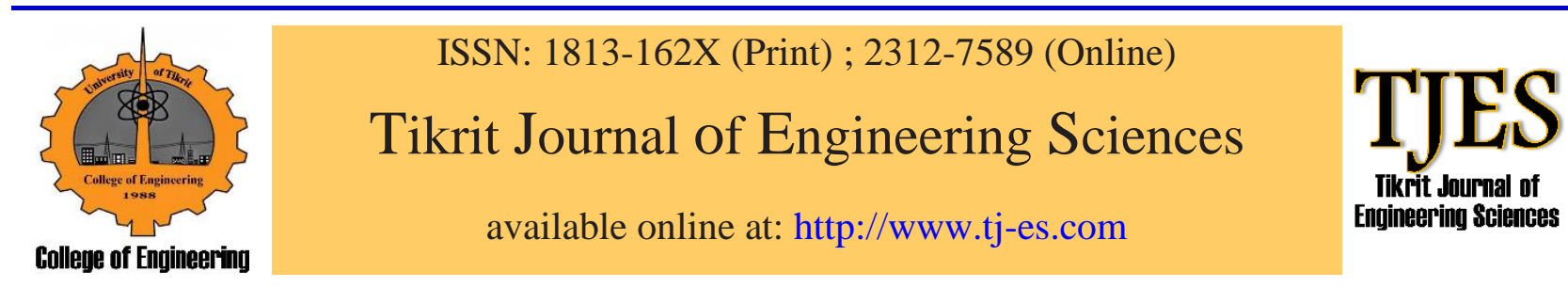

Najeeb S. Abtan

\title{
Tensile Strength, Micro-hardness and Microstructure of Friction-Stir- Welding AA6061-T4 Joints
}

\section{Mustafa S. M. Al-Janabi * \\ Department of Mechanical Engineering College of Engineering \\ Tikrit University \\ Tikrit \\ Iraq}

\section{Keywords:}

Friction stir welding

AA6061-T4

tool rotational speed

feed rate

aluminum alloy

\section{A R T I C L E I N F O}

\section{Article history:}

Received

Accepted

01 August 2018

Available online

مقاومة الثد، الصلادة المجهرية، والبنية المجهرية لوصلات (AA6061-T4) ملحومة باللحام الخلط الاحتكاكي

لحام سبائك الالمنيوم بالطرق التقليدية يخلق بعض العيوب مثل الثقوق الحارة و المسامية والفر اغات التي تعمل على خفض الخو اص الميكانيكية للملحومات، لحام الخلط

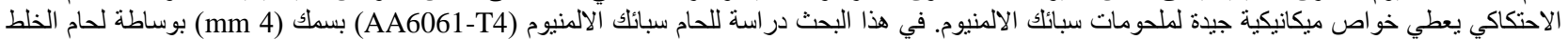

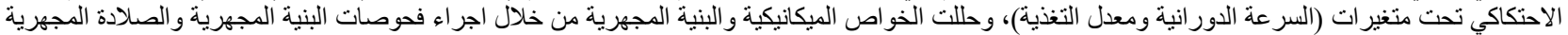

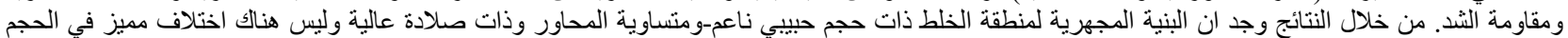

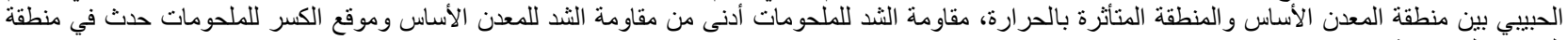

\section{INTRODUCTION}

Aluminum alloy 6061 was belongs 6 XXX series Al$\mathrm{Mg}-\mathrm{Si}$ alloys which are used in many of industries that need high strength, light weight, good formability, corrosion resistance, and hardening properties. In addition, for reducing the cost compared to $2 \mathrm{XXX}$ and $7 \mathrm{XXX}$ series $[1,2]$.

Aluminum alloy are joined by traditional fusion welding method to use as structural part, but get different welding defects such as avoid, hot cracks, porosity, and distortion would be constriction the welding zone, defects are corresponding to melting and solidification. In addition, problems of fusion welding are loss of work hardening effect, dislocation and precipitation can be happening near that weld zone [2-4].

Therefore, need welding method is recommended to minimize this defects. Friction Stir Welding (FSW) fabricated by TWI in 1991, Cambridge, UK. It is encouraging method because it gives a high weld quality of different of $\mathrm{Al}$ alloy, also can be extinguish some of defect as a result of fusion welding such as cracking and porosity [5].

The principle of FSW is a rotating tool plunges into the two edges of plate to be welded, the heat generated from the 
friction between shoulder and pin of tool and welds plate as shown in Fig. 1 which leads to soften the welds materials at a temperature low the melting point $[5,6]$.

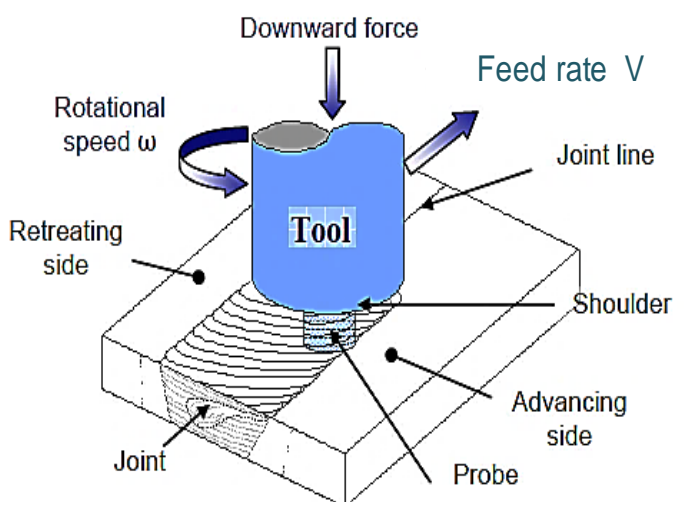

Fig. 1. schematic of FSW process and shape of welds specimens [5].

Liu et al. [3] studied the effect of tool dimension and friction stir welding parameters on mechanical properties and microstructure for 6061-T651 Al alloy. As a result, they found that free defect at a large range of tool dimension and welding parameters, also they found not different of grain size and shape from base metal (BM) to the heat affected zone (HAZ) in a significantly. Rodrigus et al. [5] studies the effect of welding parameters and tool shape on mechanical properties and microstructure of FSW for AA 6061 thin plate. The result was concluded that change in tool shape and parameter led to significant changes in materials flow at welding as well as changes in the microstructure of the weld zone. Shalin and Hiten [6] performed experimental analysis on influence of welding parameters and tool pin geometry on mechanical strength of FSW for AA6061, found that increasing the tool rotational speed, the ultimate tensile strength increases as more heat generated because high friction, also found that tool geometry is the large significant than welding parameters which influence of tensile properties of FSW. Kumbhar and Bhanumurthy [7] studies friction stir welding of aluminum 6061 alloy, General result was found the microstructure of $\mathrm{BM}$ in large than the nugget zone (NZ), since the NZ has grain size of a round $10 \mu \mathrm{m}$ and mechanical properties influence by thermal cycle as a result of frictional heat. Mohamadi et al. [8] performed lap FSW between dissimilar AZ31B and AA 6061 sheet, was used different welding parameters including tool shape, rotational speed and transverse speed. That found the increasing the tool rotational speed has increases in tensile properties and tool shape not significant in mechanical properties.

From sufficient literature survey parameters like rotational speed (rpm) with a wide range (low and high value) and feed rate $(\mathrm{mm} / \mathrm{min})$ with a near range were choose for the provide study and responses like microstructure, vicker's hardness, and tensile strength of friction stir welding for AA 6061 was investigated.

\section{MATERIALS AND METHOD 2.1. Materials}

6061-T4 aluminum alloy is used in the provide study, $4 \mathrm{~mm}$ in thickness, and by spectral analysis (in laboratories and inspection engineering department / Baghdad / Iraq), the chemical composition shown in the Table 1.

Table 1

The chemical composition of AA6061.

\begin{tabular}{lllllll}
\hline $\mathbf{S i}$ & $\mathbf{F e}$ & $\mathbf{C u}$ & $\mathbf{M n}$ & $\mathbf{M g}$ & $\mathbf{T i}$ & $\mathbf{A l}$ \\
\hline 0.767 & 0.32 & 0.12 & 0.13 & 1.1 & 0.07 & Bal. \\
\hline
\end{tabular}

The plates were cut to the dimensions of $(300 \times 100 \times 4$ $\mathrm{mm})$. A low carbon steel tool was used in this study having tapered cylinder pin shape, with shoulder diameter $20 \mathrm{~mm}$, $6 \mathrm{~mm}$ root pin diameter, $4 \mathrm{~mm}$ head pin diameter, and 3.9 mm length of pin as shown in Fig. 2.

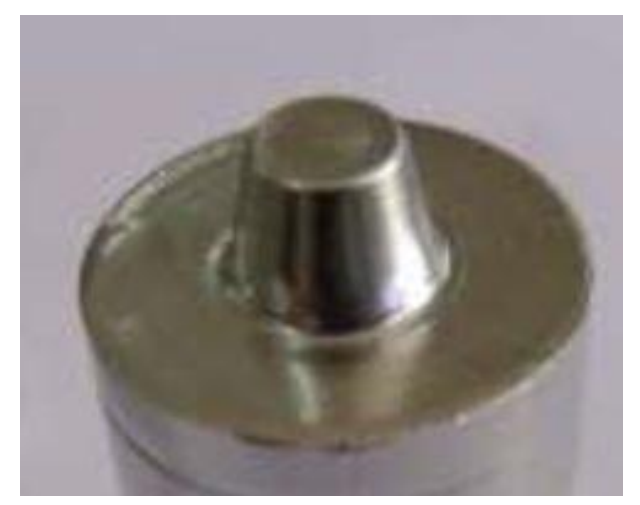

Fig. 2. Tool geometry used in the provide study.

The welding parameters were used in this paper and selected to obtain a near range of feed rate and a wide range of rotational speed (low and high value) depending on the values installed on using machine, as listed in Table 2.

The tool tilt angle ( 3 degree) was used for all samples welded, where the optimum value of the tilt angle of tool will be (2-4 degree) [9].

Table 2

Welding parameters were used.

\begin{tabular}{ccc}
\hline $\begin{array}{c}\text { Sample } \\
\text { No. }\end{array}$ & $\begin{array}{l}\text { Tool rotational } \\
\text { speed }(\mathbf{r p m})\end{array}$ & $\begin{array}{c}\text { Feed rate } \\
(\mathbf{m m} / \mathbf{m i n})\end{array}$ \\
\hline 1 & & 20 \\
2 & 690 & 32 \\
3 & & 45 \\
\hline 4 & & 20 \\
5 & 1130 & 32 \\
6 & & 45 \\
\hline 7 & & 20 \\
8 & 2000 & 32 \\
9 & & 45 \\
\hline
\end{tabular}

\subsection{Method}

Microstructure observation, micro-hardness, and tensile test were applied to the samples welding. Microstructure of all zones of welds was observed by optical microscopy. Welds cutting in a perpendicular direction to the welding center line. After polishing process, the sample etching by a solution where listed in Table 3. These were then used for optical microscopy. 
Table 3

Content of etching solution

\begin{tabular}{ll}
\hline $1 \mathrm{ml}$ & Concentrated of hydrochloric acid HF \\
$1.5 \mathrm{ml}$ & Concentrated hydrochloric acid $\mathrm{HCl}$ \\
$2.5 \mathrm{ml}$ & Concentrated nitric acid $\mathrm{HNO}_{3}$ \\
$95 \mathrm{ml}$ & Distilled water $\mathrm{H}_{2} \mathrm{O}$ \\
\hline
\end{tabular}

The vicker's micro hardness test was carried out on the cross-section perpendicular to the welding center line, using a hardness device (THV-501E) by a load $500 \mathrm{~g}$ for 5 seconds dwell time. Tensile test was carried out according to the ASTM B 557M [10] Fig. 3. Tensile tests were completed on a (Universal testing machine), at room temperature in the research laboratory air utilizing a consistent step speed of $1 \mathrm{~mm} / \mathrm{min}$. The property information for each welding was acquired by averaging two test samples

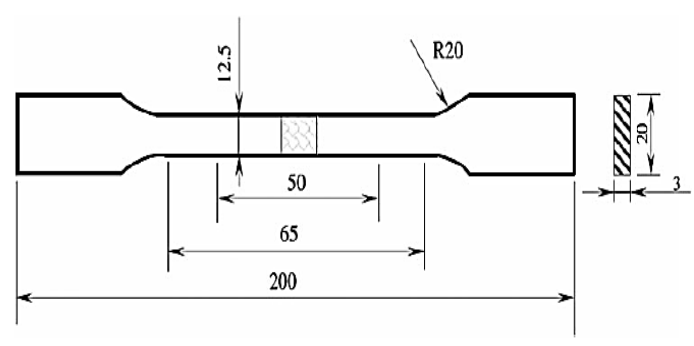

Fig. 3. Specimens tensile test was used (all dimension in $\mathrm{mm})$.

\section{RESULTS AND DISCUSSIONS 3.1. Microstructure}

The friction stir welding process map of AA6061-T4 in different parameters as can be shown in Fig. 4. From figure it can be seen the defect-free welds could be got at a wide range, but defect is shown at $(45 \mathrm{~mm} / \mathrm{min})$ with $(690$ $\mathrm{rpm}$ ) tool rotational speed due to low heat input on weld region at this conditions. On other hand, basically best mechanical properties can be got by subjecting these to product welds without defect.

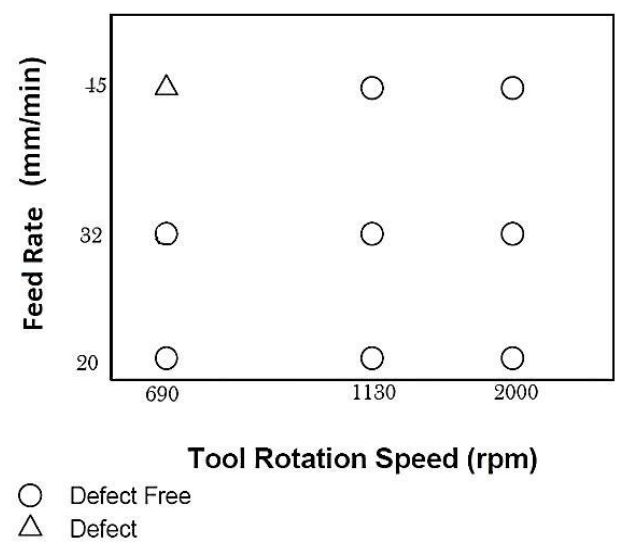

Fig. 4. Process map of AA6061-T4 welding.

Fig. 5 shows cross section of macrostructure of the friction stir welded AA6061, under different parameters. It can be seen defect-free welds at all weld zone. On other hand, four microstructural weld zones were included, I) Stir zone (SZ), II) Thermo-mechanically affected zone (TMAZ), III) HAZ, and IV) BM,

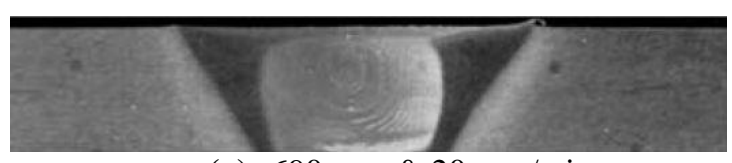

(a) $690 \mathrm{rpm} \& 20 \mathrm{~mm} / \mathrm{min}$

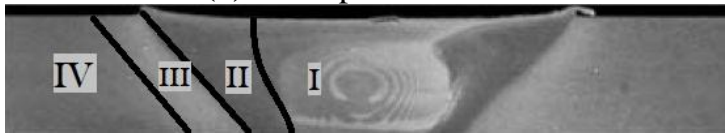

(b) $1130 \mathrm{rpm} \& 20 \mathrm{~mm} / \mathrm{min}$

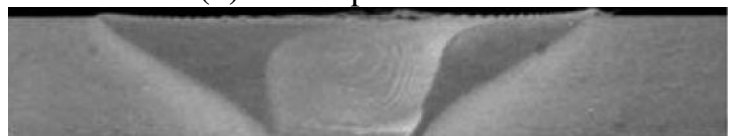

(c) $1130 \mathrm{rpm} \& 45 \mathrm{~mm} / \mathrm{min}$

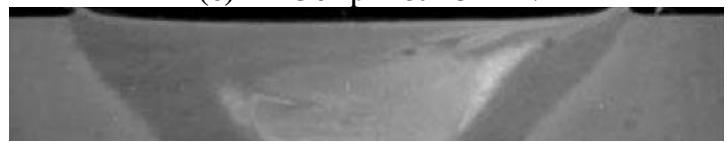

(d) $2000 \mathrm{rpm} \& 20 \mathrm{~mm} / \mathrm{min}$

Fig. 5. Macrostructure for cross-section of FSW AA6061-T4 welds.

Fig. 6 shows the optical microscopy microstructural of SZ, TMAZ, HAZ, and BM of sample welds at (690 rpm and $20 \mathrm{~mm} / \mathrm{min})$, the microstructural of both HAZ and BM were characterized by elongated grains because the manufacturing process (rolling process: is a metal forming which reduce the thickness and thickness uniform, this process led to gives a new structure and mechanical properties), and occur coarsening in HAZ as a result of thermal history that was subjected by frictional heat during friction stir welding process see Fig. 6(a) and (d).

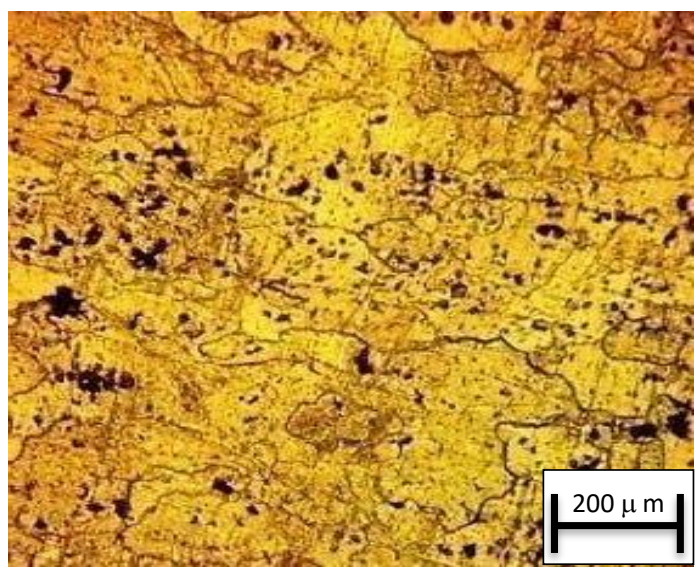

(a)

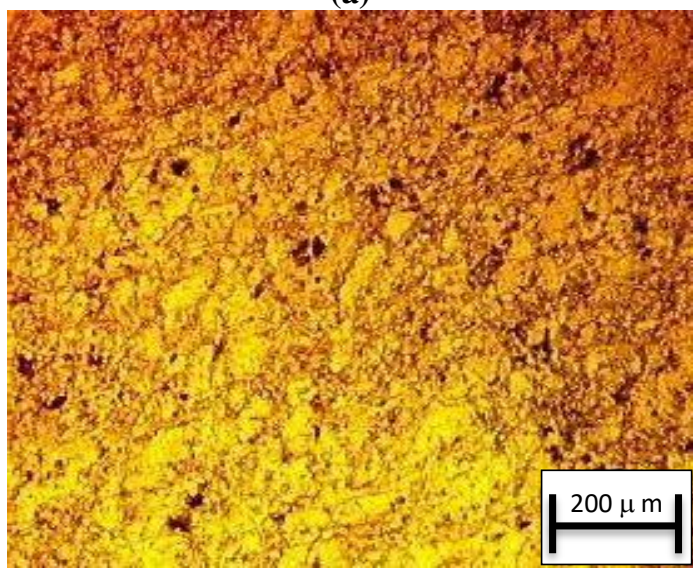

(b)

Fig. 5. (continuous). 


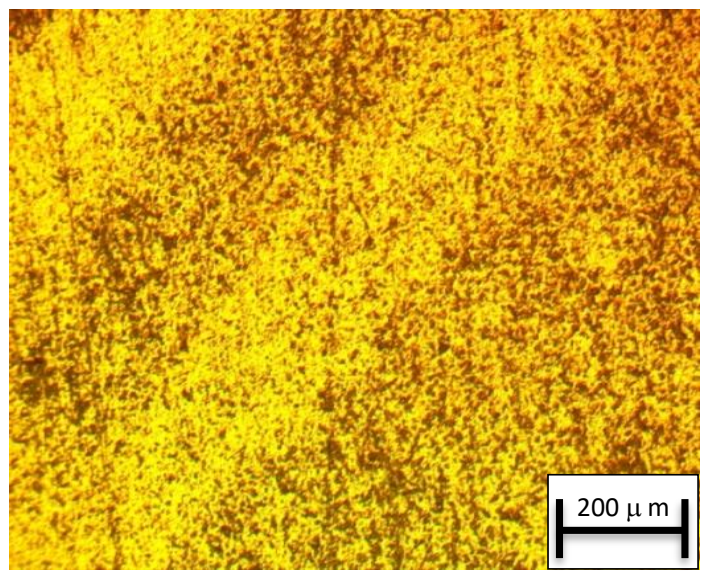

(c)

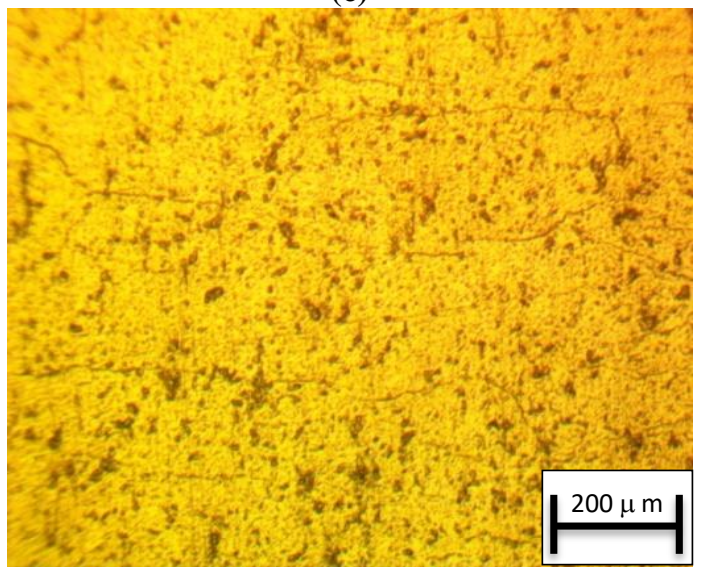

(d)

Fig. 5. Microstructrues in different zones:

(a) BM,

(b) NZ at $690 \mathrm{rpm}, 20 \mathrm{~m} / \mathrm{min}$, (c) TMAZ, and (d) HAZ.

TMAZ as be seen in Fig. 6(c) this region experience by plastic deformation, but non occurred recrystallization because inadequate deformation strain and heat input. While the SZ as shown in Fig. 6(b), it was appeared fineequiaxed grain structure, demonstrating the happening of dynamic recrystallization because too hard plastic defamation and heat input in this zone.

\subsection{Microhardness}

Fig. 7(a)-(c) shows the vicker's microhardness distribution maps of FSW AA6061-T4 welds at the crosssection and perpendicular welding center line for different welding parameters 690,1130 , and $2000 \mathrm{rpm}$ respectively, important observations can be made:

I. For the same welding parameters, the low hardness at HAZ where location outward center line weld due to subjected to the thermal history led to coarsening and dislocation of second phase particle and precipitates.

II. The high hardness at SZ for different welding parameters comparing with other zones, this inclination suggests that high hardness at this region is not function of grain structure but a function of particle size and distribution of precipitates of second phase particle. Since the grain structure is lower influenced on hardness in SZ compared to other factors.

III. For the same tool rotational speed with increasing of feed rate from 20 to $45 \mathrm{~mm} / \mathrm{min}$, the distance of HAZ decreased due to low heat input and decreased of SZ.

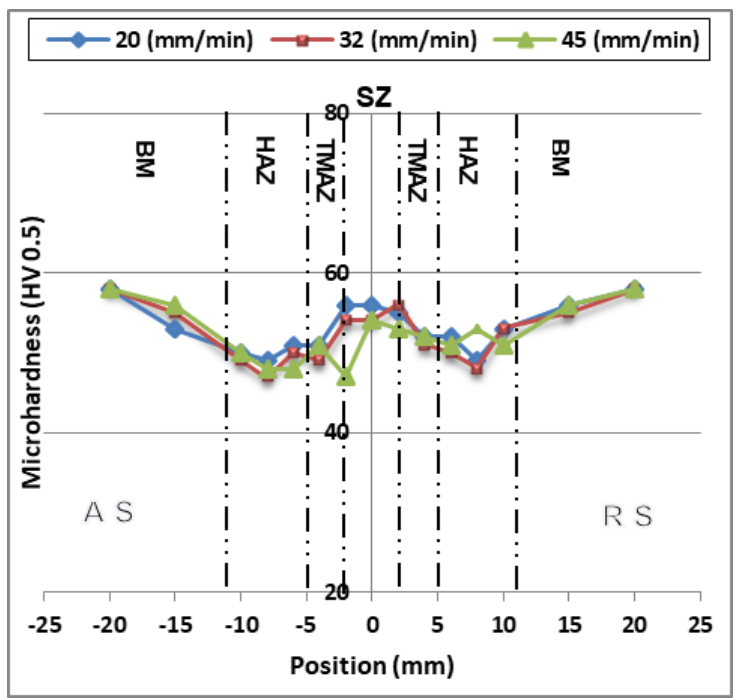

(a)

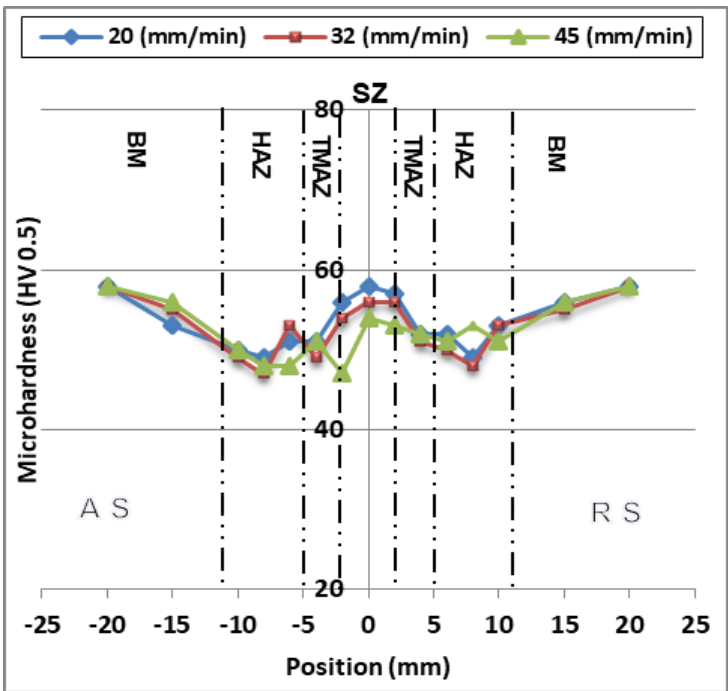

(b)

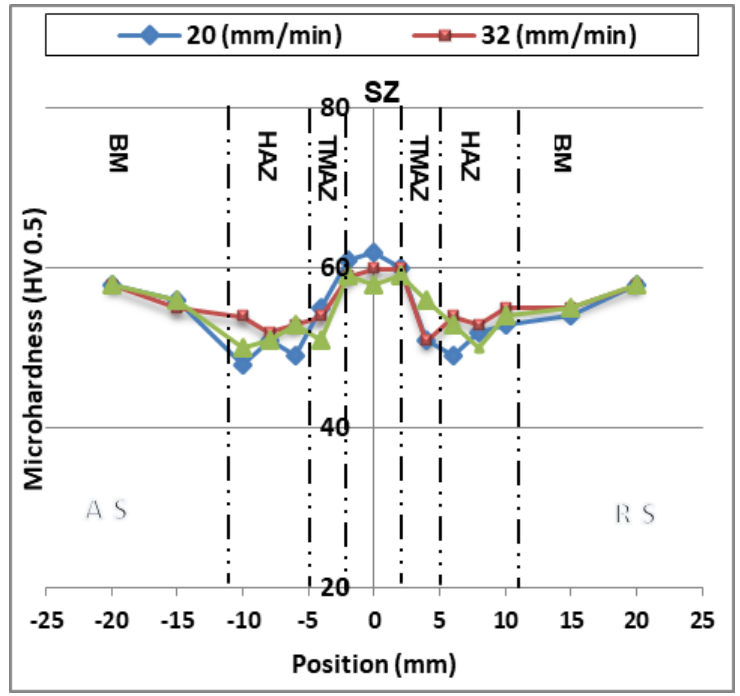

(c)

Fig. 6. Microhardness profile of the welded at travel speed $20 \mathrm{~mm} / \mathrm{min}$ and deferent rotational speed

(a) $690 \mathrm{rpm}$; (b) $1130 \mathrm{rpm}$; (c) $2000 \mathrm{rpm}$.

IV. For the same feed rate with increasing of tool rotational speed from 690 to $2000 \mathrm{rpm}$, the distance of HAZ to the joint center increased because increasing of heat input during friction stir welding process. In addition, 
the hardness of SZ was increased due to increasing of dynamic recrystallization as a result of tool rotational was increased.

V. TMAZ hardness in translation region between $\mathrm{SZ}$ and $\mathrm{HAZ}$, and the BM hardness $(58 \pm 2 \mathrm{HV})$ was not affected with change of welding parameters.

\subsection{Tensile properties}

The tensile strength of BM and FSW (6061-T4) aluminum ally welds at different rotational speeds and feed rates can be seen in Table 4 .

\section{Table 4}

Resulting tensile test for FSW (6061-T4) aluminum alloy.

\begin{tabular}{|c|c|c|c|c|}
\hline \multicolumn{2}{|c|}{ Parameters } & \multirow{2}{*}{$\begin{array}{c}\text { Ultimate } \\
\text { stress } \\
\text { (Mpa) }\end{array}$} & \multirow{2}{*}{$\begin{array}{l}\text { Elongation } \\
\quad(\mathbf{m m})\end{array}$} & \multirow{2}{*}{$\begin{array}{c}\text { Weld } \\
\text { efficiency } \\
\%\end{array}$} \\
\hline $\begin{array}{c}\omega \\
\mathbf{r p m}\end{array}$ & $\begin{array}{c}\mathrm{V} \\
\mathrm{mm} / \mathrm{min}\end{array}$ & & & \\
\hline \multicolumn{2}{|c|}{$\mathrm{BM}$} & 198.9 & 10.8 & $\begin{array}{l}--- \\
\end{array}$ \\
\hline \multirow{3}{*}{690} & 20 & 142.6 & 6.7 & 71.7 \\
\hline & 32 & 135.4 & 3.87 & 68 \\
\hline & 45 & 129.8 & 3.39 & 65.25 \\
\hline \multirow{3}{*}{$\begin{array}{c}113 \\
0\end{array}$} & 20 & 159.8 & 6.5 & 80.3 \\
\hline & 32 & 146.2 & 4.73 & 73.5 \\
\hline & 45 & 134.4 & 4.11 & 67.5 \\
\hline \multirow{3}{*}{$\begin{array}{c}200 \\
0\end{array}$} & 20 & 173.6 & 7.96 & 87.28 \\
\hline & 32 & 158.6 & 6.75 & 79.7 \\
\hline & 45 & 153.2 & 5.59 & 77 \\
\hline
\end{tabular}

From result three important findings:

I. For all the welds indicated almost elongation value regardless of FSW parameters Fig. 7, and elongation value of less than of elongation of $\mathrm{BM}$, because of fracture location of tensile specimen happen in HAZ region when considered weakest hardness zone.

II. Fig. 8 for the same tool rotational speed with increasing the feed rate from 20 to $45 \mathrm{~mm} / \mathrm{min}$, the tensile strength reduced due to increasing the hardness value.

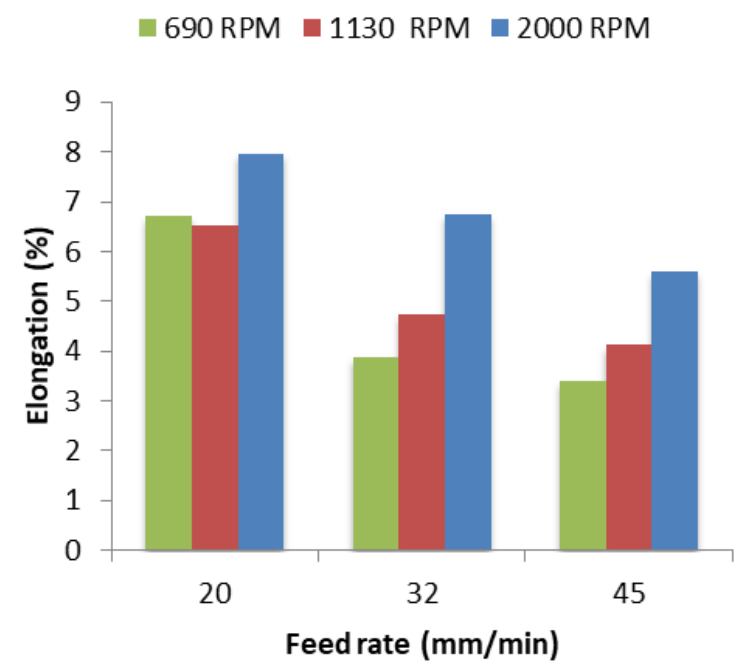

Fig. 7. Effect of feed rate on elongation of welds for different tool rotational speed; (a) $690 \mathrm{rpm}$;(b) $1130 \mathrm{rpm}$; (c) $2000 \mathrm{rpm}$.

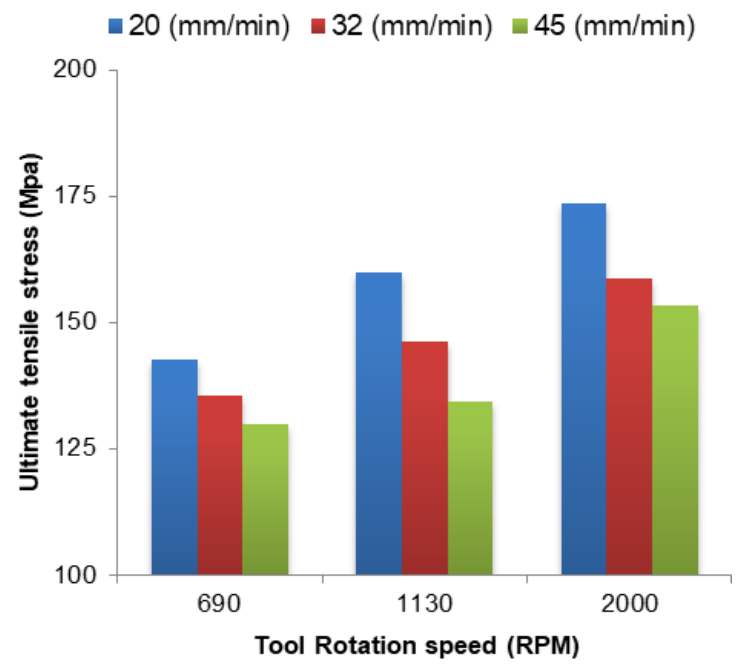

Fig. 8. Effect of tool rotational speed on tensile strength of welds for different feed rates; (a) $20 \mathrm{~mm} / \mathrm{min}$;(b) 32 $\mathrm{mm} / \mathrm{min}$; (c) $45 \mathrm{~mm} / \mathrm{min}$.

III. Fig. 9 for the same feed rate at $20 \mathrm{~mm} / \mathrm{min}$ with increasing the tool rotational speed from 690 to 2000 rpm, the tensile strength increased, the cause that as the tool rotational speed increase friction between the base metal plate and tool was used, result of this high heat input and the plastic deformation of base metal proper bonding between two edge which to be welds.

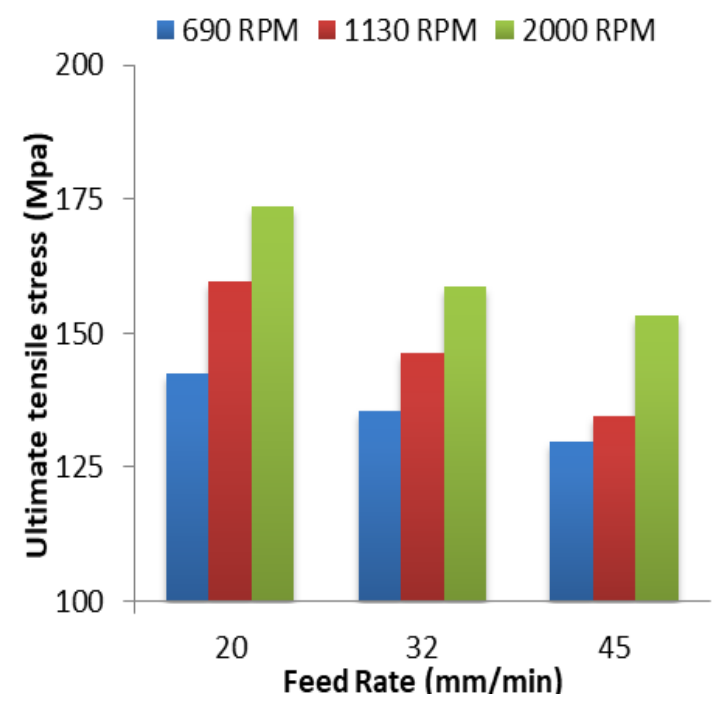

Fig. 9. Effect of feed rate on tensile strength of welds for different tool rotational speed; (a) 690 rpm;(b) $1130 \mathrm{rpm}$; (c) $2000 \mathrm{rpm}$.

IV. The fracture behavior of all tensile specimens of welds happened at the HAZ region because the weakest region of the weld. Previous study was suggested that the fracture occur due to lower hardness value at this region [3,11-13].

In this study, all tensile specimens were fractured at HAZ and translate region between HAZ and TMAZ. This prove that fracture location occur at the low hardness region, also at this region structure low bonding. From above as possible controlled of tensile properties by control of the selection of welding parameters and the low hardness value of HAZ region. 


\section{CONCLUSIONS}

In this study, the effect of welding parameters of FSW AA6061 welds on the mechanical properties and microstructures was investigated. The important conclusions are write:

i. Defect-free FSW 6061-T4 Al alloy welds were process under a various range of welding parameters.

ii. The fine-equiaxed grain of stir zone, and not significantly change from BM and HAZ at shape and size grain, but different in structural structure.

iii. The tensile properties of FSW AA6061-T4 welds increased with increasing the tool rotational speed and decrease of feed rate, and the location of friction occurred at HAZ and translate region between HAZ and TMAZ at low hardness value of this region.

iv. The hardness distribution maps were shown low hardness value at $\mathrm{HAZ}$ region because subjected to thermal history, and high hardness value in the SZ due to fine grain of this zone, size and distribution of precipitates particle as a result of dynamic recrystallization of was subjected.

\section{REFERENCES}

[1] Imam M, Racherla V, Biswas K. Effect of post-weld natural aging on mechanical and microstructural properties of friction stir welded 6063-T4 aluminium alloy. Materials \& Design 2014; 64: 675-686.

[2] Lim S, Kim S, Lee C-G, Kim S. Tensile behavior of friction-stri-welded Al 6061-T651. Metallurgical and Materials Transactions A 2004; 35 (9) :2829-2835.

[3] Liu F, Ma Z. Influence of tool dimension and welding parameters on microstructure and mechanical properties of friction-stir-welded 6061-T651 aluminum alloy. Metallurgical and materials transactions A 2008; 39 (10): 2378-2388.

[4] Malopheyev S, Vysotskiy I, Kulitskiy V, Mironov S, Kaibyshev R. Optimization of processingmicrostructure-properties relationship in friction-stir welded 6061-T6 aluminum alloy. Materials Science and Engineering: A 2016; 662:136-143.

[5] Rodrigues D, et al. Influence of friction stir welding parameters on the microstructural and mechanical properties of AA 6016-T4 thin welds. Materials \& Design 2009; 30 (6): 1913-1921.

[6] Shalin M, Hiten M. Experimental analysis on effect of tool transverse feed, tool rotational speed and tool pin profile type on weld tensile strength of friction stir welded joint of AA 6061. Materials Today: Proceedings 2018; 5 (1):487-493.

[7] Kumbhar N, Bhanumurthy K. Friction stir welding of Al 6061 alloy. Asian Journal of Experimental Sciences 2008; 22 (2): 63-74.

[8] Mohammadi J, Behnamian Y, Mostafaei A, Gerlich A. Tool geometry, rotation and travel speeds effects on the properties of dissimilar magnesium/aluminum friction stir welded lap joints. Materials \& Design 2015; 75: 95-112.

[9] Mishra RS, Ma Z. Friction stir welding and processing. Materials Science and Engineering 2005; 50 (1-2): 1-78.
[10] Standard A. B557M tension testing wrought and cast aluminum and magnesium-alloy products. 2002.

[11] Scialpi A, De Filippis L, Cavaliere P. Influence of shoulder geometry on microstructure and mechanical properties of friction stir welded 6082 aluminium alloy. Materials \& Design 2007; 28 (4): 1124-1129.

[12] Mahoney M, Rhodes C, Flintoff J, Bingel W, Spurling R. Properties of friction-stir-welded 7075 T651 aluminum. Metallurgical and Materials Transactions A 1998;29(7):1955-1964.

[13] W, Guo X, McClure J, Murr L, Nunes A. Heat input and temperature distribution in friction stir welding. Journal of Materials Processing and Manufacturing Science 1998; 7: 163-172. 